\title{
The Effect of Pollen on Some Reproductive Parameters of Male Rats
}

\author{
Güldeniz Selmanoğlu' ${ }^{1}$, Sibel Hayretdağ ${ }^{2}$, Dürdane Kolankaya ${ }^{1}$, Aslı Özkök Tüylï ${ }^{1}$ \\ and Kadriye Sorkun ${ }^{1}$ \\ ${ }^{1}$ Hacettepe University, Faculty of Science, Department of Biology, 06800 Beytepe, Ankara, \\ Turkey \\ ${ }^{2}$ Çanakkale University, Faculty of Art and Science, Department of Biology, 17100 \\ Çanakkale, Turkey
}

\section{SUMMARY}

Honeybee pollen is consumed as natural food in healthy human diet in many European and Asian countries. The aim of this study was to investigate the effect of pollen use on some reproductive parameters. In this study, mature male rats were fed on pollen of three different plant sources (Trifolium spp., Raphanus spp. and Cistus spp.) at 60 mg/per animal/ per day over a 30-day period. At the end of the treatment, testosterone levels of rats were analysed and weights of testis, epididymis, prostate and seminal vesicle were recorded. In addition, epididymal sperms were counted.

There were increases in testosterone levels, sperm counts and daily sperm production of rats fed with pollen of Raphanus spp. and Cistus spp. There were no significant changes in absolute weights, except in prostate weights. Also there were no changes in relative testis, prostate and seminal vesicle weights of rats fed on pollen, but relative epididymis weights of rats in pollen groups decreased. The results of this study show that bee pollen caused an increase in testosterone level and sperm counts of male rats. We suggest that bee pollen has an androgenic effect.

Keywords: Pollen; Rat; Reproductive parameters; Sperm counts

\section{INTRODUCTION}

Pollen is a food of perfectly balanced nutritional value. Pollen collected by honeybees contains generally $40 \%$ of proteins, essential amino acids, low amounts of fat and high levels of minerals. Pollen, which is the male seed of flowers, is required for plant fertilization.

Honeybee pollen, used by many insect species as food, contains all the essential components for life. Besides proteins, it contains several vitamins, enzymes or coenzymes, carbohydrates and hormones. In addition, pollen has very low calorie value but is a rich source of minerals, including magnesium, calcium, copper, manganese, etc. Comparing it to agricultural crops, pollen contains more proteins, iron $(\mathrm{Fe})$, thiamine, riboflavin and niacin than tomato, cabbage, apple, bread, beef or eggs of equal weight (Schmidt, 1997). 
There have been several studies about the effects of pollen on animals. Organ and body weight of rats fed on pollen for 90 days were reported to be higher than controls (Liebelt et al., 1994). Some investigators also showed that female and male rats fed on pollen were healthier looking and more bright-bristled than control animals.

When honeybee pollen is given to anemic patients, levels of hemoglobin increase considerably. It has been reported that honeybee pollen normalizes cholesterol and triglyceride levels in blood. A reduction in cholesterol and triglycerides has been observed after regular consumption of honeybee pollen. High- density lipoproteins (HDL) increase, while low-density lipoproteins (LDL) decrease (Mercola, 2003). It has also been suggested that pollen could be used for treatment of allergic reactions; when rats were fed $20 \mathrm{mg}$ pollen during five days, IgG levels increased but IgE was restrained in their blood (Palos et al., 1975). Eosinophil and lymphocyte levels in rats fed on pollen of Trifolium spp., Raphanus spp. and Cistus spp. at a rate of $60 \mathrm{mg} / \mathrm{per}$ animal/per day for 30 days were observed to increase. While neutrophile and monocyte levels decreased, different values were found in basophile leucocytes between the pollen groups. Different reductions in mesentery mast cell concentration, degranulisation and cell localisation were found. Considering the three pollen groups tested, the rats fed on Cistus spp. pollen were observed to have higher blood lymphocyte, eosinophil, haemoglobin and hematocrit values than the other animals, as well as low mesentery mast cell concentration (Kolankaya et al. 2006).

Honeybee pollen contains nearly all nutrients that are present in plant sources and required by human organism and it is used widely as food. Therefore, the present study was designed to evaluate the effects of three different pollens collected in Turkey on the reproductive parameters of rats.

\section{MATERIAL AND METHODS}

Pollen samples used in this study were collected from different localities in Bursa, Turkey. Three kinds of pollen were used in this study: Fabaceae-Trifolium spp. (A pollen); Brassicaceae-Raphanus spp. (B pollen); Cistaceae-Cistus spp. (C pollen).

Two to three months-old male Wistar albino rats were used in this experiment. The animals were obtained from the experimental Animal Production
Center of the Hacettepe University, Ankara, Turkey. Rats were randomly divided into four groups of 8 animals each. Each cage housed two rats. The first group was selected as a control group and the other three as experimental groups. Three different pollen taxa were applied to the experimental groups. Pollen A was applied to the second group of rats, pollen $B$ to the third group and pollen $\mathrm{C}$ to the fourth group. Daily pollen portions of $60 \mathrm{mg} / \mathrm{rat}$ were administered with mixed standard laboratory diet over a 30-day period. All animals were fed a standard laboratory diet ad libitum during the experiment. Water and food consumption were recorded daily, while individual animal weights were recorded weekly throughout the experiment.

At the end of the experiment, blood samples were taken from each rat for biochemical analysis after cervical dislocation. After centrifugation of blood samples at $3200 \mathrm{rpm}$ for $30 \mathrm{~min}$, serum was separated. A radioimmunoassay technique using RIA kits in 1277 model Gamma Counter was employed to measure serum testosterone levels.

The cauda epididymis was dissected and minced with scissors in $1 \mathrm{ml}$ normal saline (0.9\%). After sperm were allowed to swim out of the epididymis for $30 \mathrm{~min}$, the epididymal content was diluted 10 times with normal saline. The sperm suspension was used for sperm count using Neubauer's chamber. Sperm were counted at a magnification of X 420 under a light microscope. The sperm counting of each animal was made in duplicate and the mean was taken. A group mean was calculated by using a mean sperm count of each animal. Epididymal sperm counts were expressed as the number of sperms per cauda epididymis.

The testes, epididymis, prostate and seminal vesicles of each animal were immediately removed. Organ weights were recorded and relative organ weights of each animal calculated.

\section{RESULTS AND DISCUSSION}

Pollen contains all the essential components of life. It is not a uniform product. Pollen content changes depending on plant taxa. Various pollens may have different effects on human health. We cannot say that every pollen has similar effect on rats, some pollen can be beneficial, some other not. On the other hand, occasionally it may contain hazardous substances such as asphalt, metals or heavy metals (Matsuno, 1994; Alcici 1996; Diaz et al. 1997). Therefore, it is necessary to 
consume this natural food appropriately. In the present study, we investigated biochemical and morphological reproductive effects of pollen on male rats.

The data obtained from the testis, epididymis, prostate and seminal vesicle weights and relative organ weights of the control rats and rats fed on pollen are given in Table 2. While there were no significant changes in absolute testis, epididymis and seminal vesicle weights of rats in the pollen groups, absolute prostate weights statistically increased. There were no changes in relative testis, prostate and seminal vesicle weights of rats fed on pollen, but the relative epididymis weights of rats in pollen groups decreased (Table 2).

It has been reported that honeybee pollen in the diet acts to normalize cholesterol and triglyceride levels in blood. After regular ingestion of honeybee pollen, a reduction of cholesterol and triglycerides is observed, HDL increases, while LDL decreases. A normalization of blood serum cholesterol levels has also been seen (http://www.florahealth.com/flora/home/canada/products/r1510.asp). Selmanoğlu et al. (2007) investigated the effect of pollen on the liver and kidneys of male rats. They reported that no significant toxic effect was ob- served either in biochemical analysis or histological investigation of liver and kidneys of rats given three different pollens.

The data of testosterone levels, sperm counts and daily sperm production of rats given pollens $\mathrm{A}, \mathrm{B}, \mathrm{C}$ and the control are presented in Table 1 . There were increases in testosterone levels, sperm counts and daily sperm production of rats fed with pollen of Raphanus spp. and Cistus spp. (Table 1). Although the increases were not significantly different in statistical terms from the control, we can say that pollen caused an increase in these parameters. There is no literature available on pollen effects on testosterone levels and sperm counts.

The data obtained from testis, epididymis, prostate and seminal vesicle weights and relative organ weights of the control rats and rats fed on pollen are given in Table 2. While there were no significant changes in absolute testis, epididymis and seminal vesicle weights of rats in the pollen groups, absolute prostate weights statistically increased. There were no changes in relative testis, prostate and seminal vesicle weights of rats fed on pollen, but relative epididymis weights of rats in the pollen groups decreased (Table 2). Epididymis has im-

Table 1. Serum testosterone levels and sperm counts of rats in the control and pollen-fed groups

\begin{tabular}{lcccc}
\hline & \multicolumn{4}{c}{ GROUPS } \\
\hline Parameters & Control & Pollen A & Pollen B & Pollen C \\
\hline Testosterone $(\mathrm{ng} / \mathrm{mL})$ & $0.67 \pm 0.16$ & $0.42 \pm 0.11$ & $0.72 \pm 0.23$ & $0.91 \pm 0.18$ \\
Sperm count & $58.57 \pm 9.99$ & $56.07 \pm 7.47$ & $66.87 \pm 9.91$ & $82.71 \pm 12.91$ \\
(per cauda epididimis, $\left.\mathrm{x} 10^{6}\right)$ & $9.60 \pm 1.63$ & $9.17 \pm 1.23$ & $10.97 \pm 1.62$ & $13.56 \pm 2.11$ \\
\hline Daily sperm product $\left(\mathrm{x} 10^{6}\right)$ &
\end{tabular}

Values are given as means $\pm \mathrm{SD}$

Table 2. Organ weights and organ/body weight ratios of rats in the control and pollen-fed groups $\left(x 10^{3}\right)$

\begin{tabular}{lcccc}
\hline & \multicolumn{3}{c}{ GROUPS } \\
\hline Parameters & Control & Pollen A & Pollen B & Pollen C \\
\hline Initial weight $(\mathrm{g})$ & $146.14 \pm 7.15$ & $148.14 \pm 13.28$ & $140.37 \pm 6.65$ & $145.42 \pm 10.81$ \\
Final weight $(\mathrm{g})$ & $195.92 \pm 6.79$ & $219.28 \pm 11.31$ & $204.00 \pm 10.15$ & $214.21 \pm 7.07$ \\
Increase $(\%)$ & 49.78 & 71.17 & 63.63 & 68.79 \\
Testis absolute weight $(\mathrm{g})$ & $1.28 \pm 0.01$ & $1.35 \pm 0.04$ & $1.29 \pm 0.04$ & $1.48 \pm 0.13$ \\
$\quad$ relative organ weight $(\mathrm{g})$ & $6.59 \pm 0.19$ & $6.28 \pm 0.38$ & $6.41 \pm 0.28$ & $6.85 \pm 0.46$ \\
Epididymis absolute weight $(\mathrm{g})$ & $0.20 \pm 0.01$ & $0.15 \pm 0.01$ & $0.15 \pm 0.01$ & $0.17 \pm 0.01$ \\
$\quad$ relative organ weight $(\mathrm{g})$ & $1.03 \pm 0.06$ & $0.73 \pm 0.09^{*}$ & $0.78 \pm 0.07^{*}$ & $0.77 \pm 0.06^{*}$ \\
Prostate absolute weight $(\mathrm{g})$ & $0.23 \pm 0.02$ & $0.36 \pm 0.07^{*}$ & $0.30 \pm 0.02$ & $0.36 \pm 0.02^{*}$ \\
$\quad$ relative organ weight $(\mathrm{g})$ & $1.22 \pm 0.12$ & $1.68 \pm 0.34$ & $1.45 \pm 0.10$ & $1.68 \pm 0.06$ \\
Seminal Vesicles absolute weight $(\mathrm{g})$ & $0.58 \pm 0.04$ & $0.58 \pm 0.05$ & $0.53 \pm 0.07$ & $0.63 \pm 0.04$ \\
$\quad$ relative organ weight $(\mathrm{g})$ & $2.98 \pm 0.18$ & $2.75 \pm 0.32$ & $2.56 \pm 0.31$ & $2.93 \pm 0.16$ \\
\hline
\end{tabular}

Values are given as means \pm SD

* Significantly different statistically from the control $(\mathrm{P} \leq 0.05)$ 
portant reproductive functions, such as maturation of sperm surface antigens enabling fertilization, storage of sperm prior to ejaculation, resorption of seminiferous tubule fluid and secretion of molecules into fluid. However, the changes in epididymis weights did not affect sperm counts.

When all results were evaluated, none of the pollens was found to cause a significantly negative effect on the male reproductive system of rats. It rather has a positive effect on some reproductive parameters, such as testosterone level and sperm count. Different pollen grains caused different increases in these parameters. Finally, when pollen consumption is extended to a period longer than 30 days, we suggest that pollen may be having a benefical effect on sperm production.

\section{ACKNOWLEDGEMENT}

This study was supported by the Research Center Office of Hacettepe University (Grant No: 02.G.067).

\section{REFERENCES}

Alcici, N.M.F: Heavy metals in propolis - Practical and simple procedures to reduce the lead in the brazilian propolis. Chem. Abstr. (CA), 127: 23631, 1996.

Diaz, N.J., Quevedo, A.O., Luna, S.B: Determination of $\mathrm{Fe}, \mathrm{Mn}, \mathrm{Zn}$ and $\mathrm{Cu}$ in an ethanolic extract of Cuban propolis. Rev. Cenic. Cienc. Quim., 28: 93-95, 1997. http://www.florahealth.com/flora/home/canada/products/ r1510.asp,

Kolankaya, D., Şentürk, H., Tüylü Özkök, A., Hayretdă̆, S., Selmanoğlu, G., Sorkun, K: The effect of Trifolium, Raphanus and Cistus pollen grains on some blood parameters and mesentery mast cells. Z. Naturforsch, 61(c): 421426, 2006.

Liebelt, R.A., Calcaginetti D.: Effects of a bee pollen diet on the growth of the laboratory rat. American Bee Journal, 139(5): 390-395, 1999.

Matsuno, T.: Propolis - Its pharmacology and therapeutic effects. M.P.I.: Tokyo, 1994, 154.

Mercola, J.: The Use of Bee Pollen as a Superfood, 2003.

http://www.shirleys-wellness-cafe.com/bee.htm,

Palos E., Voiculescu Z., Andrei C.: Comparative studies concerning biochemical characteristics of the beebread as related to the pollen preserved in honey. Proceedings XXV Apimondia Congress, Grenoble, France, 1975, p. 235.

Schmidt J.O.: Bee product chemical composition and application. International Conference on Bee Product Properties, Application and Apitherapy, Israel, 1997, p. 15.

Selmanoğlu G., Hayretdağ S., Kolankaya D., Tüylü Özk̈̈k A., Sorkun K.: The effects of pollen on serum parameters and the liver and kidney tissues of rats. Pesticides and Phytomedicine, 22(1): 59-64, 2007.

Wojcicki,J., Hinek, A., Samochowiec, L.: The protective effect of pollen extracts against allyl alcohol damage of the liver. 2004. http://www.graminex.com/clinical_studies/ study48.php,

\section{Efekat polena na neke reproduktivne parametre mužjaka pacova}

\section{REZIME}

Pčelinji polen kao prirodna hrana predstavlja deo zdrave ishrane u mnogim evropskim i azijskim zemljama. Cilj ovog istraživanja je bio da se ispita delovanje polena na neke reproduktivne parametre. Mužjaci pacova su hranjeni polenom dobijenim iz tri različita biljna izvora (Trifolium spp., Raphanus spp. i Cistus spp.) i to u dnevnim dozama od 60 mg po životinji tokom perioda od 30 dana. Na kraju tretmana, analiziran je nivo testosterona i merena težina testisa, epididimisa i semenih kesica pacova. Pored toga, merena je brojnost epididimalnih spermatozoida. 
Zabeležen je porast nivoa testosterona, brojnosti spermatozoida i dnevne produkcije sperme kod pacova hranjenih polenom Raphanus spp. i Cistus spp. Nije bilo značajnih promena apsolutne težine, osim težine prostate. Takođe, nije bilo promene relativne težine testisa, prostate i semenih kesica kod pacova hranjenih polenom, ali je smanjena relativna težina epididimisa pacova u grupama koje su dobijale polen. Rezultati ovog istraživanja pokazuju da je pčelinji polen doveo do povećanja nivoa testosterona i brojnosti spermatozoida kod mužjaka pacova. Po našem mišljenju, pčelinji polen ima androgeno delovanje.

Ključne reči: Polen; pacov; reproduktivni parametri; brojnost spermatozoida 